\title{
Surface-localized Cortex-lytic Enzyme in Spores of Bacillus cereus $\mathbf{T}$
}

\author{
By W. C. BROWN AND R. L. CUHEL \\ Department of Biology, University of California, San Diego, \\ P.O. Box 109, La Jolla, California 92037, U.S.A.
}

(Received Io June 1975; revised 22 July 1975)

\section{INTRODUCTION}

Spore lytic enzymes are probably involved in germination, but their precise roles and mechanism of action are not clear, as purified preparations have not been studied. The location of spore lytic enzymes is also of interest. Strange \& Dark (I957) suggested that these enzymes might be strongly adsorbed to the outer surface of spores, although Gould, Hitchins \& King (I966) suggested that they might be weakly bound to electronegative groups on or within the core. Studies using lytic enzymes from mechanically disrupted spores (Gould \& Hitchins, I965; Gould \& King, 1969; Strange \& Dark, 1957) would not distinguish between these two possibilities.

We treated intact spores with reagents that alter spore coats (Chambon, DuPraw \& Kornberg, I968; Gould \& Hitchins, 1963, 1965) and demonstrated that spores of Bacillus cereus $\mathrm{T}$ contain a surface-localized, cortex-lytic enzyme.

\section{METHODS}

Organism and preparation of spores. Bacillus cereus, obtained from T. Hashimoto, Loyola University, Maywood, Illinois, U.S.A., was grown and sporulated in modified G medium (Hashimoto, Black \& Gerhardt, 1960) and the spores purified by two-phase partition (Sacks \& Alderton, I96I). They were then washed five times with cold distilled water, once with I $\mathrm{M}-\mathrm{NaCl}$, and five times with cold distilled water. No sporangia or intact vegetative cells were visible after these treatments. The spores were lyophilized or stored in suspension at $-20{ }^{\circ} \mathrm{C}$.

Chemicals. Urea (reagent grade) was obtained from Matheson, Coleman, Bell Co., Los Angeles, California, U.S.A., and 2-mercaptoethanol from Sigma.

Enzyme assays. Crude enzyme extracts were prepared by a modification of a method previously used to sensitize spores to lysozyme (Chambon et al. I968). Lyophilized spores ( $100 \mathrm{mg}$ dry $\mathrm{wt} / \mathrm{ml}$ ) were suspended in $7 \cdot 2 \mathrm{M}$-urea containing $10 \%(\mathrm{v} / \mathrm{v}) 2$-mercaptoethanol at $\mathrm{pH} 3.0$ (UME). The mixture was incubated at room temperature for $2 \mathrm{~h}$ and centrifuged at $10000 \mathrm{~g}$ for $15 \mathrm{~min}$. The supernatant fractions were dialysed for $3 \mathrm{~h}$ at $4{ }^{\circ} \mathrm{C}$ against 400 vol. of $\mathrm{I} 0 \mathrm{~mm}$-tris- $\mathrm{HCl}$ buffer, $\mathrm{pH} 8 \cdot 0$, containing $0.2 \mathrm{M}-\mathrm{NaCl}$. The dialysing fluid was changed every hour. Cortical fragments were prepared by treating disrupted spore pellets with solutions containing urea, mercaptoethanol and sodium lauryl sulphate as described by Hashimoto, Frieben \& Conti (1972). Enzyme activity was measured by a turbidimetric procedure using a Beckman DBGT spectrophotometer as described previously (Brown, 1973). One unit of enzyme activity corresponds to a decrease in extinction of $0.001 / \mathrm{min}$ at $600 \mathrm{~nm}$. 
Table I. Distribution of lytic enzyme in I $g$ of spores of B. cereus $\mathrm{T}$

Extracts were assayed separately. The total activity present in each fraction was determined by adding up the amounts present in all of the extracts.

\begin{tabular}{|c|c|c|c|c|}
\hline \multirow[b]{2}{*}{ Spore sample } & \multirow[b]{2}{*}{ Description of fraction } & \multicolumn{2}{|c|}{ Enzyme activity } & \multirow[b]{2}{*}{$\begin{array}{c}\text { Specific activity } \\
\text { (units/mg } \\
\text { protein) }\end{array}$} \\
\hline & & $\begin{array}{l}\text { Total activity } \\
\text { (units/500 mg } \\
\text { spores) }\end{array}$ & $\begin{array}{c}\text { Percentage } \\
\text { of } \\
\text { total }\end{array}$ & \\
\hline \multirow[t]{3}{*}{ UME-treated spores } & $\begin{array}{l}\text { UME extracts from intact } \\
\text { spores }\end{array}$ & 36852 & $9 \mathrm{I}$ & 1450 \\
\hline & $\begin{array}{l}\text { Buffer extract from disrupted } \\
\text { spores }\end{array}$ & 0 & 0 & 0 \\
\hline & $\begin{array}{l}\text { UME extracts from spore } \\
\text { fragments }\end{array}$ & 3642 & 9 & 328 \\
\hline \multirow[t]{2}{*}{ Untreated spores } & $\begin{array}{l}\text { Buffer extracts from disrupted } \\
\text { spores }\end{array}$ & 57 II & $8 \cdot 7$ & I3I \\
\hline & $\begin{array}{l}\text { UME extracts from spore } \\
\text { fragments }\end{array}$ & 59586 & $9 I \cdot 3$ & 2422 \\
\hline
\end{tabular}

Distribution of lytic enzyme. The distribution of lytic activity between the surface and core fractions of $\mathrm{I} g$ of spores was determined as follows: Half the spore sample was treated with UME repeatedly, and the extracts were assayed for lytic activity and protein. The UME-treated spores were suspended in buffer and disrupted in a Braun homogenizer, as described below, and the buffer extract assayed for lytic activity and protein content. The spore fragments were extracted repeatedly with UME and the extracts assayed for activity and protein. The extracted fragments were discarded. The other half of the spore sample was disrupted without prior treatment with UME, and the buffer extract assayed for lytic activity and protein. The spore fragments were extracted repeatedly with UME, and the extracts assayed for activity and protein. The spore fragments were discarded.

Disruption of spores. Spores $(20 \mathrm{mg}$ dry $\mathrm{wt} / \mathrm{ml}$ ) in $20 \mathrm{ml}$ of $0.2 \mathrm{M}$-sodium phosphate buffer $\mathrm{pH} 7 \cdot 0$, were disrupted by shaking with glass beads ( $6 \mathrm{~g}$; type I, Sigma) in a Braun cell homogenizer (Bronwill Scientific Co., Rochester, New York, U.S.A.). The suspension was shaken for 2 min while cooled with short bursts of $\mathrm{CO}_{2}$ applied every 5 to $6 \mathrm{~s}$. The extent of breakage was assessed using a phase-contrast microscope. Usually seven 2-min cycles were required for complete breakage.

\section{RESULTS}

To determine if lytic enzyme could be extracted from intact spores, the spores were extracted with UME solution at room temperature and a portion of the extract was incubated with a suspension of cortical fragments at $37^{\circ} \mathrm{C}$. This suspension lost $45 \%$ of its original turbidity in 15 min, whereas cortical fragments incubated in buffer alone or with boiled extract lost less than $2 \%$ of the original turbidity during this interval. About half of the cortex-lytic activity was readily removed from the spore surface, but three additional treatments with UME were necessary to solubilize the enzyme completely.

The distribution of lytic activity was determined in spores before and after treatment with UME (Table I). When spores were treated with UME before disruption, most of the lytic activity was found in the extract. No activity was detected in the buffer extract 
of these spores. However, when the fragments from the disrupted spores were soaked in UME a small amount of enzyme was solubilized. Conceivably this enzyme might have been present in the spore core and became adsorbed to surface components as additional sites were exposed during the initial extraction with UME. Studies are in progress to determine whether this hypothetical 'core' enzyme has the same substrate specificity as the 'surface' enzyme. When untreated spores were disrupted, about $9 \%$ of the total cortex-lytic activity was found in the buffer extract. Most of the enzyme was solubilized by soaking the spore fragments in UME. This fraction might correspond to the 'surface' enzyme obtained by treating intact spores with UME. This discrepancy in the total amount of activity obtained from the two spore preparations cannot be explained at present.

When spores were incubated in germination medium, the initial rate of germination of UME-treated spores was fivefold less than that of untreated spores. More than $99 \%$ of the untreated spores lost refractility in $15 \mathrm{~min}$, whereas a comparable loss did not occur in the UME-treated spores until after $60 \mathrm{~min}$, suggesting that the cortex-lytic enzyme might be involved in germination. Alternatively, UME treatments may remove other components from the surface that are necessary for germination. When samples of spores were plated on rich media, the UME-treated spores produced the same proportionate number of colonies as untreated spores.

We conclude that most of the cortex-lytic activity is probably localized on the surface of $B$. cereus $\mathrm{T}$ spores. The enzyme could be adsorbed on the cortex or trapped between the various protein coat layers. Warth (1972) reported the presence of four enzyme activities in spores of $B$. cereus $\mathrm{T}$ : muramidase, $\mathrm{L}$-alanine amidase, D-alanine carboxypeptidase, and $N$-acetylglucosamine deacetylase. Studies are in progress to determine which of these enzymes is released during UME treatment of intact spores and spore fragments.

The observation that isolation of cortex-lytic activity by mechanical disruption of spores in buffer yielded only a fraction of the enzyme obtainable by treatment with UME, should facilitate the rapid isolation of large quantities of spore lytic enzymes for purification and characterization.

This study was supported by a National Science Foundation grant GB40035, and by an American Cancer Society institutional grant. We thank Carrie Wilson and Angie Nakamoto for technical assistance, and J. Spizizen and S. Brody for helpful discussions.

\section{REFERENCES}

Brown, W. C. (1973). Rapid methcds for extracting autolysins from Bacillus subtilis. Applied Microbiology 25, 295-300.

Chambon, P. E., DuPraw, J. \& Kornberg, A. (1968). Biochemical studies of bacterial sporulation and germination. IX. Ribonucleic acid and deoxyribonucleic acid polymerases in nuclear fractions of vegetative cells and spores of Bacillus megaterium. Journal of Biological Chemistry 243, 5101-5I09.

Gould, G. W. \& Hitchins, A. D. (1963). Sensitization of bacterial spores to lysozyme and to hydrogen peroxide with agents which rupture disulphide bonds. Journal of General Microbiology 33, 4I 3-423.

Gould, G. W. \& Hitchins, A. D. (1965). Germination of spores with Strange \& Dark's spore lytic enzyme. In Spores III, pp. 213-22I. Edited by L. L. Campbell and H. O. Halvorson. Ann Arbor, Michigan: American Society for Microbiology.

Gould, G. W., Hitchins, A. D. \& KING, W. L. (I966). Function and location of a 'germination enzyme' in spores of Bacillus cereus. Journal of General Microbiology 44, 293-302.

Gould, G. W. \& KING, W. L. (1969). Action and properties of spore germination enzymes. In Spores IV, pp. 276-286. Edited by L. L. Campbell. Bethesda, Maryland: American Society for Microbiology.

Hashimoto, T., Black, S. H. \& Gerhardt, P. (1960). Development of fine structure, thermostability and dipicolinate during sporogenesis in a Bacillus. Canadian Journal of Microbiology 6, 203-2 I 2. 
Hashimoto, T., Frieben, W. R. \& Conti, S. F. (1972). In Spores V, pp. 409-415. Edited by H. O. Halvorson, R. Hanson and L. L. Campbell. Washington, D.C.: American Society for Microbiology.

SACKs, L. E. \& Alderton, G. (1961). Behavior of bacterial spores in aqueous polymer two-phase systems. Journal of Bacteriology 82, 33I-34I.

Strange, R. E. \& Dark, F. A. (I957). A cell-wall lytic enzyme associated with spores of Bacillus species. Journal of General Microbiology 16, 236-249.

Warth, A. D. (1972). Action of spore lytic enzymes on the cortex. In Spores V, pp. 28-34. Edited by H. O. Halvorson, R. Hanson and L. L. Campbell. Washington, D.C.: American Society for Microbiology. 